\author{
A.M. Dossanova (iD) , I.A. Abdikadyr* \\ Al-Farabi Kazakh National University, Kazakhstan, Almaty \\ *e-mail:indira.kaznu@gmail.com
}

\title{
ADAPTATION OF REPATRIATE-KAZAKH CHILDREN
}

The article describes the process of adaptation of repatriate-Kazakh pupils returning to the country in society, in particular at school. Due to the emotional, psychological, linguistic barriers of repatriateKazakh pupils, their inability to quickly adapt to the social environment, the situation of integration into society and school is not always easy. The issue of adaptation of repatriate-Kazakh children is multifaceted and relevant for modern society. If we turn to the social adaptation of repatriate-Kazakh children, then the purpose of adaptation is not always complete assimilation. The object of the study was the analysis of individual questions and answers of repatriate-Kazakh pupils of middle school in the Republic of Kazakhstan. Repatriate-Kazakh children are sensitive, adaptable to the situation, actions and changes in society, within the school, able to express themselves freely. In order to determine the language adaptation of repatriate Kazakh students, a method of targeted interviews was conducted. Analysis of the data received from the respondents was performed and described. As a result of the study, the stages of life processes of repatriate-Kazakh pupils, including social, cultural, psychological, as well as language communication with the local population, were identified in the field of education. In Kazakhstan, the difficulty of rapid language adaptation of repatriate children is based on several factors. Barriers to language adaptation of repatriate-Kazakh pupils are formulated.

Key words: repatriate-Kazakh, repatriate, oralman, migrant, adaptation.

\author{
А.М. Аосанова , И.Ә. Әбдіқадыр* \\ Ә^-Фараби атындағы Қазақ ұлттық университеті, Қазақстан, Алматы қ. \\ *e-mail: indira.kaznu@gmail.com \\ Репатриант-қазақ балаларының бейімдекуі
}

\begin{abstract}
Мақалада елімізге оралып жатқан репатриант-қазақ оқушылардың қоғамдағы, атап айтқанда, мектеп қабырғасындағы бейімделуі үлерісі сипатталады. Репатриант-қазақ оқушылардың эмоционалдық, психологиялық, тілАік келергілерінен, әлеуметтік ортаға жылдам бейімлеле алмағандықтан, қоғамға, мектепке интеграциялану жағдайы үнемі жеңіл, ұтымды бола бермейді. Репатриант-қазақ балалардың бейімделу мәселесі көпқырлы және қазіргі қоғам үшін өзекті болып табылады. Мектеп жасы - этникалық қазақ оқушылары үшін этникалық сәйкестілік пен әлеуметтену процесінің маңызды кезеңі. Репатриант-қазақ балалардың әлеуметтік бейімделуіне жүгінетін болсақ, онда бейімделудің мақсаты әрқашан толық ассимиляция бола бермейді. Зерттеу нысанына Қазақстан Республикасындағы орта сынып репатриант-қазақ оқушылардың өзіндік сұрақ жауаптары та^данды. Репатриант-қазақ балалары сезімтал, қоғамдағы, мектеп қабырғасында болып жатқан жағдайға, іс-әрекеттер мен өзгерістерге бейімделгіш, өз ойларын еркін жеткізе алатын тұлғалар. Репатриант-қазақ оқушылардың тілдік бейімделуін анықтау мақсатында нысаналы сұхбат әдісі жүргізілді. Респонденттерден алынған мәліметтер сипатталды, та^дау жасалынды. Зерттеу нәтижесінде репатриант-қазақ оқушылардың өмірлік үдеріс кезеңі, оның ішінде әлеуметтік, мәдени, психологиялық, сондай-ақ, жергілікті халықпен тіл арқылы қарым-қатынас жасауы, білім беру саласында да өз көрінісі анықталды. Қазақстанда репатриант балалардың жылдам тілдік бейімделуінің қиындығы бірнеше факторларға негізделгенін көрсетеді. Репатриант-қазақ оқушылардың тілдік бейімделудегі кедергілері тұжырымдалды.
\end{abstract}

Түйін сөздер: репатриант-қазақ, репатриант, оралман, мигрант, бейімделу.

\section{А.М. Аосанова, И.А. Абдикадыр* \\ Казахский национальный университет имени аль-Фараби, Казахстан, г. Алматы *e-mail:indira.kaznuQgmail.com}

\section{Адаптация детей репатриантов-казахов}

В статье описан процесс адаптации школьников-репатриантов, возвратившихся с семьями в Казахстан, а также особенности интеграции таких социальных групп в казахстанское общество, в частности, в школьную среду. Необходимо отметить, что вслеАствие эмоциональных, 
психологических, языковых барьеров казахов-репатриантов, их неспособности быстро аАаптироваться к социальной среде, процесс интеграции не всегда бывает легким. Проблема аАаптации репатриантов-казахов детского возраста многогранна и актуальна А^я современного общества. Школьный возраст - важный этап в процессе этнической илентичности и социализации Аля этнических казахов-школьников. Если обратиться к социальной аАаптации детейрепатриантов, то целью аАаптации не всегда является полная ассимиляция. Объект исследования - анализ индивиАуальных вопросов и ответов школьников-репатриантов. Аети репатриантовказахов чувствительно адаптируются к ситуации, действиям и изменениям в обществе, внутри школы. А^я определения языковой адаптации учащихся репатриантов-казахов была выбрана и использована методика целевого интервью. В исследовании проведен анализ данных, полученных от респондентов. В результате исследования были выявлены этапы жизненных процессов учащихся репатриантов-казахов, включая социальное, культурное, психологическое, а также языковое общение с местным населением в сфере образования. В статье описаны факторы и причины, осложняющие быструю языковую аАаптацию детей-репатриантов, а также возможные барьеры, сопутствующие описываемому процессу.

Кмючевые слова: репатриант-казах, репатриант, оралман, мигрант, адаптация.

\section{Introduction}

The independence of the Republic of Kazakhstan was the beginning of the mass return of repatriate Kazakhs to their historical homeland. This process began to increase, especially after the adoption of the Law "On Migration" on June 26, 1992. (Law, 2011).

Along with repatriates, Kazakh language, ancestral traditions, international life, information and experience are migrating. We also need the cultural values that ethnic Kazakhs have accumulated and mastered abroad. What people learned from the Kazakh-Chinese people in China, the KazakhMongols in Mongolia, and the Kazakh-Iranians in Iran is wealth, resources and treasures.

Repatriation was of interest to our state the whole range of reasons:

- Firstly, repatriation will help to equalize the demographic situation, to compensate for the loss of past years;

- Secondly, repatriates have a great experience of adaptation and survival in conditions of alien environment and market relations can have an impact on the transformation of the economic mentality of Kazakhstanis;

- Thirdly, Kazakh foreigners are carriers of knowledge original Kazakh culture and language, which is a real thing contribution to the spiritual heritage of the nation. And, finally, repatriation partly presented as an integral part of the national idea (Abildina, 2017: 5).

Oka N. notes Kazakhstan has been promoting repatriation of ethnic Kazakhs under the slogan that it is the obligation of the state to grant its co-ethnics the right to return to their historical homeland. Yet at the same time, by failing to provide enough support for immigrants and making them feel abandoned by their homeland, the Kazakh government in fact continues to create people who are not necessarily loyal but rather disappointed with and critical of the government (Oka, 2013: 9).

One of the most important elements of the Soviet legacy is the widespread belief among Kazakhs that they and their culture, including their language, bear a natural link to their particular territory, which today extends as far as Kazakhstan's borders. A corollary of this view is a belief that, in independent Kazakhstan, members of the titular nationality have a right or even obligation to promote their language as an element of groupness, especially among their co-ethnics (Fierman, 2005: 400).

Language is the basis of communication, so special attention is paid to language integration. Repatriate Kazakhs' knowledge of the language of the country of immigration is a key indicator of their integration into labor, social and cultural life. All host countries pay special attention to language adaptation in integration programs, but each country determines the amount of language assistance. The reason why repatriate-Kazakh families moved to their homeland is that their children are educated in their historical homeland, develop their abilities and further create favorable social conditions. It also involves graduating from university, developing professional skills and getting a job.

Cerny A. states that the demand for the repatriate-Kazakh programme raises new issues. It creates new problems for Kazakhstan as new arrivals struggle to gain a foothold economically and socially, increasing competition for work and schooling, but it illustrates the disconnection between the legal infrastructure and the grand vision of the newly-formed state under former President Nursultan Nazarbayev for Kazakhstan as a nation (Cerny, 2010: 7). 
First of all, it is important to ensure that repatriateKazakh children adapt quickly and successfully upon their return. Repatriate Kazakh students have to overcome the first successful language, cultural and psychological adaptation in order to adapt easily to society and school.

Shepansky Y. divides the process of adaptation of a person in the new social environment into four stages:

The first stage is the stage of awareness: at this stage a person understands the need to behave differently in the new social environment, he does not accept the value system of the new social environment, but only the rules and laws of behavior.

The second stage is the stage of tolerance: at this stage the tolerant relationship between the person and the new social environment is formed, other value systems and behavioral relationships are recognized.

The third stage is characterized by the stage of individual recognition of the values of the new social environment and perception of the environment.

The fourth stage - assimilation, the formation of a complete unity of the social environment and value systems of the subject. An individual renounces old values by acquiring new ones. The result of this adaptation is assimilation; the individual fully accepts the system of values formed in the new social environment (Shepansky, 1969: 9).

If we turn to the social adaptation of repatriate Kazakh children, and then the purpose of adaptation is not always complete assimilation. Adaptation is a stage of life process for repatriate Kazakhs, including social, cultural, economic, psychological, as well as language communication with the local population. It is also reflected in the field of education.

According to Zimnyaya I.Y., the process of adaptation of a person is due to the conscious perception of the objective environment, secondly, human activity is always important in the adaptive environment, and thirdly, a person not only passively perceives the process of adaptation to his lifestyle, but also purposefully can change (Zimnyaya, 1997: $55)$.

Bekmakhanova K. E. states that adaptation is a process and result of a certain relationship between the individual and the social environment (Bekmakhanova, 1983: 4).

The concept of "adaptation" is interpreted as a social process, in particular, the individual is recognized as an adaptive, adaptive system of the social environment and actively interacts in the process of social adaptation.
The process of adaptation of repatriate-Kazakh students returning to the country is complicated. The situation of their integration into society and school is not always easy. Repatriate-Kazakh pupils' emotional, psychological, language barriers affect their rapid adaptation to the social environment. The issue of adaptation of repatriate-Kazakh children is multifaceted and relevant for modern society.

Repatriate migration is one of the problems that subject of the study for many scientists in Kazakhstan. Amangul Sh. (2010) argues that Kazakh immigrants returning to their historic homeland are faced with a large set of problems, such as "sociocultural adaptation" as well as issues of "civillegal environment." Although the Kazakhstan government aims to provide different benefits and values for returners, these benefits are not enough for starting and adapting to new and higher priced life conditions. One of the big problems faced by ethnic migrants is language skills. Until now Kazakhstan has had two official languages Russian and Kazakh language. Lack of Russian language skills is one of the common barriers for ethnic Kazakhs hunting for jobs without Russian language knowledge, but with ambition, aspiration, and education.

However, Bokaev B. (2015) discusses more on the integration and adaptation of Kazakh returnees in Kazakhstan is constrained by negative factors. These include a lack of knowledge of the Russian language, lack of job skills, lack of education, ignorance of the law, and the psychology, mentality and culture of the local population.

There are language barriers for various reasons. Kazakhstan, Russia and some CIS countries use the Cyrillic alphabet, Turkey and Western Europe use the Latin alphabet, and China, Iran and Pakistan use the ancient Kazakh alphabet (based on the Arabic alphabet). Kazakh repatriate children from Turkey, China, Iran and Pakistan, who know the Kazakh language, cannot read or write because they do not know the Cyrillic alphabet (The situation of repatriates in Kazakhstan, Review, 2006: 33).

Kalshabayeva B. K. and Seisenbayeva A. S. (2013) declare that the adaptation process is the language issue. Language is the foundation of the relationship, so its importance can notbeoverestimate in society integration process. Knowledge of the state language by compatriots is the key indicator of integration into the labor market, social and cultural life of the country. All states pay particular attention to immigrants concerning their language skills in context of their adaptation. But each country has its own way to determine the amount of aid to study of language. 
Krumm H. and Plutzar V. analyze as far as second language acquisition research in migration contexts has taken place we can say that the language identity of migrants is very complex for several reasons: the language shift they experience due to their migration and their language biographies are influenced by the linguistic situation and language policy in the countries of origin (Krumm \& Plutzar, 2010: 2).

Pogrebitskaya E. M. in the work "Adaptation of migrant children in the context of education" is based on three levels of work in the development of the program of adaptation of migrant children:

teaching - provides extracurricular extracurricular activities in languages or another subject for differentiated groups;

communication - conversation with classmates about the history of the country of origin of repatriate children in the educational hour;

cultural enrichment is based on the purposeful organization of leisure time, the study of culture through intercultural activities.

Repatriate-Kazakh children are in particularly difficult conditions: the child differs from the environment of his new location with their culture; he is, in most cases, is socially unprotected, does not know or badly know the language of the school system, as well as the psychology on which the language is based. The integration of repatriateKazakh children into society is an essential issue due to locals, repatriates are alienable. They are treated differently as outsiders by locals.

\section{Materials and method}

The repatriate-Kazakh children as being central phenomenon they need integration and adaptation analysis and understanding. With the help of special interview questions consequently, relevant information about their adaptation life experience obtained. During the interview repatriate-Kazakh pupils were able to tell their stories and repatriateKazakh pupils' feelings, expressions and emotions have taken into account. Conducting interview questions, a micro-analytic picture of repatriateKazakh pupils' problems was successfully obtained and helps to understand the main phenomenon of this study. By homogeneous sampling method repatriate-Kazakh pupils from China were chosen and the chosen respondents study at Kazakhstani school. In general, four repatriate-Kazakh high school pupils were participated in an interview. The given names are pseudonyms in our analysis chosen by respondents.
This practical research analyzes the adaptation process of repatriate-Kazakh pupils at schools and followed by research questions: What problems do the repatriate-Kazakh pupils face at school in Kazakhstan? How do they cope with these challenges?

This research holds an attention for educators and government to develop special seminars or programs for teachers and parents on the integration of repatriate-Kazakh children into schools.

This study based on pupils who recently arrived to Kazakhstan (Aisana, Dana, Ali and Sultan) and at this time consciously experiencing the school life. Aisana started going to school from $6^{\text {th }}$ grade and now she is in her $7^{\text {th }}$ grade. Dana started going to school from $9^{\text {th }}$ grade and she is in the $10^{\text {th }}$ grade. Ali and Sultan also started going to school a year ago, at the moment they are in the $9^{\text {th }}$ grade.

Aisana's story. She had never lived in Kazakhstan before as being a third generation Kazakh who came from China. She states that upon arrival to her hometown, she noticed that her classmates mixed two Kazakh and Russian languages. Dominating language was Russian. It was difficult to socialize with her peers, so she kept being silent. Nevertheless, she states that local Kazakh language is different from they use in China and it was very embarrassing for her not knowing the Kazakh language. She declares that they use archaic Kazakh in China.

Aisana explains that she was good at Maths, that's due to education system in China. They put a lot of focus on education and the pupils study hard every day. Therefore, her ability showed their peers' interest in her and the country she came from. Soon, she was able to have a relationship with her classmates. However, the teachers had a negative attitude towards her. She states that a Russian teacher once shouted at her very loud for not understanding the lesson. The Russian teacher did not like her and teacher thinks that everyone should master Russian, but she did not want to understand Aisana came from China. At last, she ignored studying Russian. Aisana believes that all her difficulties about the languages. She noted that the adaptation of repatriate-Kazakh children to school and class depend on the teachers. She also needed time to be able to write in Cyrillic and read. Later, Aisana states that her classmates helped her with Russian while she helped them in science. The history teacher noticed her efforts and eagerness on studying Kazakh history and teacher as being strict liked Aisana. History teacher gave extra additional history books to get knowledge well.

Dana's story. She moved to Kazakhstan in 2019 with her family. They live in Almaty region 
now. Dana notes that she is very happy being in Kazakhstan, due to her grandfather who used to tell not only about their home country, but also its Kazakh tradition, culture, customs. Her uncle taught her to write and read in Kazakh language by Cyrillic alphabet while being in China. As being at Kazakhstani School she anyway had a language barrier, Dana couldn't understand her classmates' Kazakh, it was differ from her Kazakh. She also couldn't understand them because they use too many Russian words in their speech. She often isolated from her peers owing to her lack of language competence. She declares that once her classmates couldn't solve the math task on the board, so she approached to them and solved it. Therefore, her ability made her classmates gave a positive picture. Dana notes: 'her math teacher asked the way how she solved the task, however the teacher couldn't understand well her way of solving the task'. As the relationship with teachers, she states that not all the teachers accept her. Some teachers didn't show a positive attitude towards Dana. She got used to adapt more quickly as her uncle taught Cyrillic. She still has a language problem with Russian. She had problems with the teachers and the education system. Teachers didn't understand her as she came from other country.

Ali's story. Ali noted that in the early days he did not understand some Kazakh words, not only Russian. He said that he felt bad and ashamed because he did not know the Kazakh language well. Her family speaks Kazakh and Chinese, so Russian was a very different language for him. When his classmates asked him a question in Russian, he didn't understand. He asks them to speak only in Kazakh. Several of her classmates discriminated against him because he did not speak Russian well. There were days when he felt uncomfortable because Ali himself could not speak Russian well. It is still very difficult to learn Russian. He sits like a dumb, of course he tries his best, but he feels seeming his classmates are laughing at him. He doesn't like his Russian teacher, so he doesn't want to learn Russian. His parents can't speak Russian and they can't teach him. They have their own work and do not have time to do school homework with him. In his spare time he likes to play the dombra. Now at school meetings the class teacher makes him to sing and play the dombra on the stage of the school. His ability made a mutual understanding between his classmates. $\mathrm{He}$ started having a good relationship with them after all. He thinks that everyone in Kazakhstan should speak the Kazakh language first and his desire to use the Latin alphabet in Kazakhstan.
Sultan's story. Sultan is in his $9^{\text {th }}$ grade now. He points out that one of the difficulty he faced was still a language. First of all, he could not write in Cyrillic, and the lessons were difficult, especially in Kazakh, literature and Russian language. There are a lot of language classes in China. He pointed that he knew English well. He also noted that he would like to learn a lot of Russian classes at school. $\mathrm{He}$ is very happy to be back in her homeland. He thinks that he has to help his younger siblings and he needs to master the Russian language to find a good job in the future. His classmates help him a lot in Russian language. If the Sultan helps his classmates in English, they will help Sultan to read correctly in Kazakh, to clarify the rules and translations in Russian language. In general, he speaks more Kazakh with his friends on the street, where he lives. Sultan showed his friends that he was an interesting boy and that he would share his knowledge of school law in China. He taught them some Chinese words. However, Sultan was very happy to move to Kazakhstan, however he states that he had a difficult time getting used to school.

\section{Results and Discussion}

These practical findings have highlighted: 1) challenges repatriate-Kazakh pupils facing in Kazakhstani school and 2) how they deal with them. This work revealed that repatriates experience language barrier in Kazakh and Russian languages.

The results of four repatriate-Kazakh pupils' relationships with their classmates are very good. In the process of support, the child's parents, teachers, the environment, the owner of each specific optimal situation (Slusareva, 2014: 29). According to respondents claim, a good relationship happened due to their skills, ability, international status and knowledge. Also, the knowledge and skills of four repatriate-Kazakh pupils in mathematics helped them to communicate with their classmates. In this regard, the confidence of repatriate-Kazakh pupils has increased. They also got along well with teachers they are good at. The second reason is that repatriate-Kazakh pupils come from a developed, large country, and local Kazakh children are interested in the culture and language of China. These reasons helped the repatriate-Kazakh pupils to communicate with their classmates. In addition, the participation and activity of repatriate-Kazakh children in school activities showed their openness and activism. However, the language difficulties of repatriates were evident from the first day of school 
in Kazakhstan. They had difficulty in speaking and writing in Kazakh.

Repatriate-Kazakh pupils know Kazakh language better, but they do not understand the local people's dialect in Kazakh, which is different from their Kazakh. The Cyrillic was a big problem for them to face for the first time. We notice repatriateKazakh pupils spend a lot of time and effort to learn the Cyrillic alphabet, they could not learn it immediately. In fact, their inability to speak or write Russian is still a major language barrier for them. Ali's initial incompetence in Russian showed that he was initially discriminated against and ashamed of his classmates. In general, all repatriate-Kazakh pupils did not know Russian, did not accept it immediately, did not show fast and good results in Russian, and were exposed to teachers' anger and negative attitude from teachers. Aisana noted the teachers had a negative attitude towards her. She states that a Russian teacher once shouted at her very loud for not understanding the lesson. The Russian teacher did not like her and teacher thinks that everyone should master Russian, but she did not want to understand Aisana came from China. At last, she ignored studying Russian. Aisana believes that all her difficulties about the languages. We see that repatriate-Kazakh pupils need time to adapt to the new environment, society and education system. These repatriate-Kazakh pupils trust themselves and their classmates more rather than their parents. According to Sultan, his classmates helped him translate from Russian, explain the rules and learn Russian language.

\section{Conclusion}

This interview study enabled us to understand the main phenomenon of repatriate-Kazakh pupils face today. The analysis results show repatriate-
Kazakh pupils' adaptation at Kazakhstani school and overcoming the language barrier. School age is an important stage in the process ethnic identity and socialization. These results also show that teachers in Kazakhstan do not take into account the culture of the country, the education system, the alphabet used by Kazakh children from abroad. Repatriate-Kazakh children expect support and trust from their classmates. The task of parents is not only to acquaint the child with the traditions and family structure, but also with the culture of the place they live and with the peculiarities of people' with whom their children will interact. Measures of social and pedagogical support should create conditions for successful adaptation of repatriateKazakh children.

The teacher-student relationship is central in any school and any system of education. Low teachers' expectations towards migrant students generally have a negative effect on their performance. Teachers have to take into consideration the repatriate-Kazakh pupils' language competence and support them. Repatriate-Kazakh children's inability to adapt psychologically / emotionally also leads to difficulties in interaction. The study found that repatriate-Kazakh children at school are more likely to speak Russian in society, which contributes to language barriers. The main challenge is to learn Russian. Widespread use of Russian along with Kazakh makes it relevant. Repatriate-Kazakh children, who are ethnic Kazakhs, are educated in Kazakhstani schools. As mentioned above, the first language barrier is the lack of knowledge of the Kazakh. It is also necessary to increase the language competence of children, the development of the Kazakh language as an interlingual communication. The main difficulty for repatriate Kazakh children is learning Russian. The Russian language is of interest not only in theory but also in practice.

\section{References}

Абильдина Г. С. Социокультурная и языковая адаптация детей репатриантов в условиях современного Казахстана // Матер. Междунар. науч.-практ. конф. - Астана, 2017. - 220 с.

Amangul Sh. Ethnic Immigration Policy Implementation (1992-2009) // The Mongolian Journal of International Affairs. - 2013. $-250 \mathrm{p}$.

Bokayev B. "Invisible problems of ethnic migrant in Kazakhstan: Legal regulations and issues of human rights // Cornell University. $-2015 .-203$ p.

Бекмаханова К. Е. Проблема психологической адаптации студентов. - Алма-Ата: Знание, 1983. - 340 с.

Cerny A. China Kazaks and the Oralman immigration policy in Kazakhstan // Practical Action Publishing, Pastoralism. - 2010. $-130 \mathrm{p}$.

Fierman W. Kazakh Language and Prospects for its Role in Kazakh "Groupness" // Ab Imperio. - 2005. - 431 p.

Heckmann F. Education and the Integration of Migrants // European forum for migration studies. Bamberg: 2008. - 73 p.

Kalshabayeva B.K. and Seisenbayeva A.S. World Academy of Science // Engineering and Technology // International Journal of Humanities and Social Sciences. - 2013. - № 6 (7). - 1629 p. 
Krumm H. \& Plutzar V. Tailoring language provision and requirements to the needs and capacities of adult migrants // University of Vienna. - 2010. - № 5.14 p.

«Халықтың көші-қон туралы» Қазақстан Республикасының 2011 жылғы 22 шілдедегі № 477-IV Заңы http://www.adilet. zan.kz.

Oka N. (2013) A note on ethnic return migration policy in Kazakhstan: changing priorities and a growing dilemma. $223 \mathrm{p}$

Погребицкая Е. М. Адаптация детей-мигрантов в условиях образовательной организации // Пермский педагогический журнал. - 2015. - № 7. - 111 c.

Overview. The situation of repatriates in Kazakhstan. - Almaty, 2016. - P. 32. (in English).

Щепаньский Я. Элементарные понятия социологии. - М.: Прогресс, 1969. - 239 с.

Слюсарева Е. С. Комплексное сопровождение субъектов инклюзивного образовательного процесса: из опыта экспериментальной работы // Журнал Вестник Университета (ГУУ). - М., 2014. - №6. - 295 с.

Зимняя И. А. Педагогическая психология. - М.: Логос, 1997. - 384 с.

\section{References}

Abildina G. S. Sotsiokulturnaya i yazykovaya adaptatsiya detey repatriantov v usloviyakh sovremennogo

Kazakhstana [Sociocultural and linguistic adaptation of children of repatriates in the conditions of modern

Kazakhstan] // Mater. Mezhdunar. nauch.-prakt. konf., Astana: 2017. - 220 p. (in Russian).

Amangul Sh. Ethnic Immigration Policy Implementation (1992- 2009). The Mongolian Journal of

International Affairs. . - 2013. - 250 p. (in English).

Bokayev B. "Invisible problems of ethnic migrant in Kazakhstan: Legal regulations and issues of human

rights // Cornell University. - 2015. - 203 p. (in English).

Bekmakhanova K. E. Problema psikhologicheskoy adaptatsii studentov. [The problem of psychological adaptation of students] - Alma-Ata; Znanynya, 1983 - 340 p. (in Russian).

Cerny A. China Kazaks and the Oralman immigration policy in Kazakhstan. Practical Action Publishing, Pastoralism. - 2010. - 130 p. (in English).

Fierman W. Kazakh Language and Prospects for its Role in Kazakh "Groupness" // Ab Imperio. - 2005. - 431 p. (in English).

Heckmann F. Education and the Integration of Migrants. European forum for migration studies. // European forum for migration studies. Bamberg: 2008. - 73 p. (in English).

Kalshabayeva B. K. and Seisenbayeva A. S. World Academy of Science // Engineering and Technology

International Journal of Humanities and Social Sciences. - 2013. - № 6 (7). - 1629 p. (in English).

Krumm H. \& Plutzar V. (2010) Tailoring language provision and requirements to the needs and capacities of adult migrants // University of Vienna. - 2010. - № 5. 14 p. (in English).

«Khalıqtın koshi-qon turaly» Qazaqstan Respublikasının 2011 jılg1 22 shildedegi № 477-IV Zany [Law of the Republic of Kazakhstan dated July 22, 2011 № 477-IV On migration] http://www.adilet.zan.kz. (in Kazakh).

Oka N. (2013) A note on ethnic return migration policy in Kazakhstan: changing priorities and a growing dilemma. 223 p. (in English).

Pogrebitskaya E. M. Adaptatsiya detey-migrantov v usloviyakh obrazovatel'noy organizatsii [Adaptation of migrant children in the context of an educational organization ] // Permskiy pedagogicheskiy zhurnal. - 2015. - № 7. - 111 p. (in Russian).

Overview. The situation of repatriates in Kazakhstan. - Almaty. - 2016. - 32 p. (in English).

Shepansky Y. Elementarnye ponyatiya sotsiologii. [Elementary concepts of sociology ] - Moskva: Progress, 1969. - 239 p. (in Russian).

Slyusareva E. S. Kompleksnoye soprovozhdeniye sub"yektov inklyuzivnogo obrazovatel'nogo protsessa: iz opyta eksperimental'noy raboty [Comprehensive support for subjects of an inclusive educational process: from the experience of experimental work] // Zhurnal Vestnik Universiteta (GUU). - Moskva, 2014. - №6. - 295 p. (in Russian).

Zimnyaya I. A. Pedagogicheskaya psikhologiya. [Pedagogical psychology] - Moskva: Logos, 1997. - 384 p. (in Russian). 